\title{
The Lecture-Performance: Implementing Performative Pedagogy in Literature Class
}

\author{
Ana Giménez Calpe
}

Department of English and German Philology, Universitat de València, Spain.

\begin{abstract}
In recent years the performative has gained importance within the pedagogical field and has opened new perspectives in educational research. Experience has shown that the integration of performative elements in the learning process allow teachers to involve learners emotionally and cognitively. The present paper deals with a learning experience performed with students in the course "German Literature (2nd language)" at the University of Valencia. From the perspective of Performative Pedagogy, students are asked to carry out a research project and then transfer the acquired knowledge to the theatrical format that must be didactic: a LecturePerformance. This activity highlights the benefits of students' autonomous and cooperative learning, as well as the development of students' performative competence, with which they achieved deeper levels of understanding and improved their retention of what was studied. The teacher evaluation and a questionnaire carried out by the students at the end of the activity confirm the achievement of the initial objectives.
\end{abstract}

Keywords: Lecture-Performance; Performative Pedagogy; Literature Class; Applied Theatre. 


\section{Introduction}

The need to implement innovative methodologies in the university environment has opened a new path in the acquisition of communication skills for university students. At the same time recent research has explored the benefits of integrating body and movement in cognitive processes (Wilson 2002: 625). In this paper we analyse a teaching and learning experience based on the pedagogical concept that results from applying performative approaches in educational contexts. Our proposal is an example of the so-called applied theatre (Prentki \& Preston 2009: 12) as it explores a possible application of the performing arts to pedagogy, particularly to the teaching and learning of literature. Specifically, the paper presents how to integrate the practice of Lecture-Performance in the classroom, a relatively new phenomenon that can be used as an alternative for any situation that requires an oral presentation. The activity was carried out with a group of students in the course "German Literature (2nd language)" at the University of Valencia, where students had to do research in groups on specific content from the subject matter and then transfer the results of their research to the theatrical format of a Lecture-Performance.

\section{Theoretical Framework: The Lecture-Performance as part of Performative Pedagogy}

The term "performative" refers to a complex concept that has been applied heavily in a variety of disciplines over the years in both humanities and social sciences. First used in linguistics, with Austin's speech act theory, the concept has also become a key term in arts and theatre science ("performance)" as well as in gender studies ("performativity"). In recent years the performative has gained importance within the pedagogical field and has opened new perspectives in educational research. In their introduction to the anthology Performative teaching, learning, research, Susanne Even and Manfred Schewe define performative pedagogy with the following characteristics: it is action-oriented, so that verbal transmission is an action in itself, and it focuses on the processes of teaching (Even $\&$ Schewe 2016: 176). According to an action-oriented concept of teaching, students are not passive recipients of the contents transferred to them by teachers. Knowledge is not transmitted unidirectionally, but rather produced among all the agents involved in the learning process. Moreover, as Christoph Wulf and Jörg Zirfas already pointed out in Pedagogy of the Performative, the perspective of the performative in educational contexts emphasizes the "reality-constituting processes" that are part of pedagogical behaviour, as well as "the correlation of body and language, power and creativity" (Wulf \& Zirfas 2007: 10). Performative Pedagogy puts into practice the results of recent studies in neuroscience that have investigated the effects of movement-based learning in contrast to learning without movement (Sambanis 2016: 208). In his proposal for the integration of performative elements into foreign language education, Manfred Schewe proposes using 
the body in a conscious way as part of the learning process (Schewe 2011). Certain voice exercises as well as space relation exercises are necessary so that both teachers and students improve their performative competence and become aware of their physical presence.

A very specific and interesting manifestation of performative didactics is the LecturePerformance, a relatively new phenomenon that could be characterized as a hybrid between art and science/research. Its origins lie in Conceptual Art and the criticism of institutions of the 1960 s and 1970s. ${ }^{1}$ Since the beginning of the 21 st century there has been a renaissance of the Lecture-Performance as a result of the widespread belief among artists that "consciousness stemming from teaching and learning can lead to a new way to live in society" (Milder 2011: 13).

The Lecture-Performance as such can be found in the artistic, but also in other cultural, social, political or even scientific fields. This diversity shows the richness of the format, as it can be an alternative for any situation that requires an oral presentation (Brandau 2015: 7). As the term itself implies, such an alternative presentation combines traditional elements of oral presentation ("lecture") with other more creative elements of theatrical representation ("performance"). In other words, as in a lecture, specific content is transmitted, but this didactic process is achieved by integrating performative elements, like body, voice and physical presence.

\section{A classroom experience: The Lecture-Performance as presentation of a research project}

The following experience was carried out with a group of students in the course "German Literature (2nd language)" at the University of Valencia. Our course is one of the subjects involved in the INNOVA-TEA project, which since the 2015-2016 academic year has been financed by the Servei de Formació Permanent $i$ Innovació Educativa (Centre for Continuing Education and Innovation) of the University of Valencia. The project brings together different methodological innovation actions with a common denominator: the application of dramatic techniques in the classroom. The INNOVA-TEA project, which started in 2015 with six subjects involved taught by professors from the University of Valencia, has managed to increase its scope by incorporating a much larger number of professors from other Spanish and foreign universities, as well as high school teachers (21 members at present).

\footnotetext{
${ }^{1}$ Robert Morris is regarded as the forerunner of the Lecture-Performance with his Art Ready Made " 21,3 " created in 1964. See Peters 2011: 180 .
} 


\subsection{Characteristics of the course and planning of objectives}

The course "German Literature (2nd language)" is taught in the second semester of the second year in different degrees at the Faculty of Philology at the University of Valencia: Degree in English Studies, Degree in Catalan Studies, Degree in Classical Studies, Degree in Hispanic Studies and Degree in Modern Languages and Literatures (with German as a second language). In the seminar, authors and works of German language literature from the late 19th century to the present day are studied, paying special attention to the historical, social and cultural context.

For a part of the final grade of the course, students had to carry out in groups a research project that culminated with the representation of a Lecture-Performance. ${ }^{2}$ In order to do so, students formed small research teams (between 3 or 5 students) at the beginning of the seminar and chose a topic from the subject matter on which they wanted to investigate further. At the end of the academic year they presented the results of their research to their classmates with a Lecture-Performance. The evaluation of their Lecture-Performances took into account the originality of the format (the application of dramatic techniques) as well as the didactic potential of the performance. At the end, students were able to benefit not only from their own research, but also from the research carried out by their classmates.

For the design of this activity, which students carried out as a work in progress throughout the course, the following learning objectives were determined:

1. To acquire more knowledge about the chosen subject and learn to do research independently.

2. To improve performative competence and creativity.

3. To learn to work cooperatively.

4. To become an active part of the learning process.

\subsection{The activity}

The work done by the students consisted in distinct phases:

First of all, each research group had to go deeper into the topic they had chosen. Following the premises of cooperative learning, each member of the group assumed a role in the research process, so that, as a result of the positive interdependence among the students, only the effective work of all the group members could ensure the final product. ${ }^{3}$ After

\footnotetext{
2 The students of the subject were given the choice between the Lecture-Performance and the Radio-Podcast as two different formats for their research projects, but in this paper we will only focus on the groups that opted for the Lecture-Performance.

${ }^{3}$ Barbara J. Millis describes positive interdependence as follows:'Positive interdependence means that teachers give students a vested reason to work together on a task, usually through the nature and structure of a task that has been designed to encourage cooperation and provide challenges a single student could not meet”. Millis 2010: 5.
} 
having shared the research each of them had carried out independently, the group had sufficient information on the subject to start with the writing of the Lecture-Performance script.

In a second phase, students had to transfer the acquired knowledge to a theatrical format that had to be didactic. The application of dramatic techniques becomes a central point of reference. Therefore, students attended a workshop outside of the scheduled class hours, which intended to help them in designing their Lecture -Performance. In this workshop the teacher helped students to train the learners' performative competence and to integrate elements such as body, voice, physical presence and space into their presentations.

At the end of the course students performed their Lecture-Performances, which were recorded by the faculty's audio-visual technician. The evaluation of the LecturePerformances was done following a series of criteria that had been available from the beginning of the course on the class Moodle-Platform. These criteria took into account the following elements: 1) the research phase (depth of treatment of the subject matter) 2) the Lecture-Performance's creation (text structure, originality, creativity and dynamism) and 3) the final result (the Lecture-Performance), taking into account aspects such as performance, stage props, costumes, gestures, movement and space management.

Finally, to complete the project, students had to submit a report (5-7 pages) that had to include: 1) the most important ideas of the research they had wanted to convey and 2) a reflection on the functioning of teamwork. In this part the group had to describe the meetings, the distribution of tasks, possible conflicts as well as conflict resolution and negotiation processes. These reports are of great importance, as they allow students to reflect not only on the final product, but on the whole research and learning process (Calero 2019: 379).

\subsection{Analysis of the Lecture-Performances}

The students enrolled in the course formed twelve groups. Six of them opted for the RadioPodcast and six for the Lecture-Performance as the format to present the results of their research. We will now focus on the groups that chose the Lecture-Performance.

Although there are certain similarities between the groups (the occasional use of German, as well as subject-specific vocabulary, such as names of literary movements or related to the portrayed historical and cultural context), the format chosen by each of the groups is quite varied: from the television interview with the author Erika Mann about her experience in exile (group one) to a television report about Büchner's influence on Paul Celan's work, with a large number of archive images (group two), or the theatrical representation of Irmgard Keun's literary works with a voiceover that reflects on them (group three). In addition, other groups opted for completely fictional scenes that allowed the groups to 
present the chosen works and authors in a didactic way. In these cases, the students were able to present more complex or abstract concepts in a clearer way, as they had more freedom to create the context that best suited their educational objectives and interests. Other elements shared by the last three groups are the use of humour, as well as attempts to introduce elements of everyday situations that would allow a greater identification among the spectators. Thus, one of the groups (group four) staged Bertolt Brecht writing a letter to the editor of a newspaper to show his disagreement with the criticism received and to explain, as a way of claim, his concept of epic theatre. The fifth group, meanwhile, staged the visit of two young people to a retirement home to visit their grandparents, who happen to be Ernst Jünger and Erich Maria Remarque. The different conceptions about the First World War that these two authors reflected in their works are approached from a transgenerational perspective, which brings the subject studied closer to the current context of the students. Finally, the sixth group was transformed into a theatre group that wanted to perform Frank Wedekind's "Lulu Plays". As in the other groups, the play was placed in a context known to the students and full of references to their daily experiences. Moreover, the situation made it possible to integrate interesting meta-theatrical reflections.

\subsection{Analysis of results}

After evaluating the students' Lecture-Performances and collecting the results of a questionnaire to evaluate the students' satisfaction, we consider that the following objectives were achieved:

1. To acquire more knowledge about the chosen subject and learn to do research independently.

The students' Lecture-Performances show the research work carried out, which was also presented in an explicit way in the group reports. In the questionnaire, students valued the first phase of the project positively: fundamentally, the need to work cooperatively in the research phase. By adopting the role of researchers, students consider the learning process more engaging and their discoveries and conclusions more significant.

2. To improve the performative competence and get creative.

What students valued most was the opportunity to develop creative work and to see how they had been able to transfer the results of their research into a format such as a LecturePerformance. In view of the final outcome of their projects, that is, the LecturePerformances, the learners improved their performative competence. By integrating performative elements, like body and voice in the learning process, the students improved their retention of what was studied. Compared to a more traditional approach of HEI teaching, the bodily-kinaesthetic action helped them to achieve deeper levels of understanding. Moreover, such a creative activity brought variety and enjoyment to the 
learning process, what increased motivation and improved the students' awareness and focus.

3. To learn to work cooperatively.

The benefits of classroom-based cooperative approaches are well documented (e.g. Millis 2010). The complexity of the discussed activity is so high that it must be addressed jointly by the research group, and not individually. For both the research and the creative phase students had to work together. In their questionnaires, students appreciated the challenges of the cooperative work and the mechanisms they used to solve their problems. However, some of them acknowledged that not all members of the group had worked the same way and that it was not fair that they should all have the same grade. To avoid this problem, students had to reflect in the final reports how the research had been distributed, which allowed the teacher to take into account the contribution of the individual students.

4. To become an active part of the learning process.

The activity enabled students to become an active part of the learning process. In the questionnaire students valued very positively a methodology that promotes the active and autonomous participation of the student. The students felt that they were not passive recipients of knowledge, but rather, that they had collaborated in the production of the content of the subject. As they never lost sight of the need for their performances to be didactic, their Lecture-Performances helped their classmates to learn more about the subject matter. Thus, students' learning is not limited to the topic they have researched, as they can also learn through their classmates' Lecture-Performances.

\section{Conclusions}

In this paper we have discussed a teaching experience that integrates the LecturePerformance into the classroom, as it was the format chosen by several students of the course "German Literature (2nd language)" to present the results of their research project. We consider that the initially proposed objectives were achieved with this activity. This assessment is based on our experience as teachers in the classroom, but also on a questionnaire carried out by the students at the end of the activity. The positive feedback on the activity reinforces the conviction of the teachers involved in the INNOVA-TEA project that this performative methodology is much closer to the needs and expectations of students. In future research we plan to implement more complex quantitative analyses and continue the study with more validation and testing instruments. 


\section{Acknowledgment}

This work is part of the INNOVA-TEA project funded by the Centre for Continuing Education and Innovation of the University of Valencia (Servei de Formació Permanent $\mathrm{i}$ Innovació Educativa). Project UV-SFPIE_PID19-1098225.

\section{References}

Brandau, J. B. (2015). Lecture Performance. Versuch einer Begriffsfindung. Berlin: epubli. Calero Valera, A. R. (2019). Lecture-Performance als Gruppenarbeit. In M. Barras, K. Karges, T. Studer \& E. Wiedenkeller (Eds.), IDT 2017. Band 2: Sektionen (pp. 375379). Berlin: Erich Schmidt Verlag.

Even, S. \& Schewe, M. (Eds.) (2016). Performatives Lehren Lernen Forschen. Performative Teaching Learning Research. Berlin: Schibri.

Milder, P. (2011). Teaching as Art: The Contemporary Lecture-Performance. PAJ, 97, 1327.

Millis, B. J. (2010). Why Faculty should adopt Cooperative Learning Approaches. In B. J. Millis (Ed.), Cooperative Learning in Higher Education. Across the Disciplines, Across the Academy (pp. 1-9). Sterling: Stylus.

Peters, S. (2011). Der Vortrag als Performance. Bielefeld: transcript.

Prentki, T. \& Preston, S. (Eds.). (2009). The Applied Theatre Reader. London and New York: Routledge.

Sambanis, M. (2016). Drama Activities in the Foreign Language Classroom Considerations from a Didactic-Neuroscientific Perspective. In S. Even \& M. Schewe (Eds.), Performatives Lehren Lernen Forschen. Performative Teaching Learning Research (pp. 206-221). Berlin: Schibri.

Schewe, M. (2011). Die Welt auch im fremdsprachlichen Unterricht immer wieder neu verzaubern - Plädoyer für eine performative Lehr-und Lernkultur! In A. Küppers, T. Schmidt \& M. Walter (Eds.), Inszenierungen in Fremdsprachenunterricht (pp. 20-31). Braunschweig: Diesterweg.

Wilson, M. (2002). Six Views of Embodied Cognition. Psychonomic Bulletin \& Review, 9(4), 625-636.

Wulf, Ch. \& Zirfas, J. (2007). Performative Pädagogik und performative Bildungstheorien. Ein neuer Fokus erziehungswissenschaftlicher Forschung. In Ch. Wulf \& J. Zirfas (Eds.), Pädagogik des Performativen. Theorien, Methoden, Perspektiven (pp. 7-40). Weinheim and Basel: Beltz. 